\title{
Correction to: Reforming State-Owned Enterprises in a Global Economy: The Case of Vietnam
}

Hege Merete Knutsen and Do Ta Khanh

Correction to:

Chapter 5 in: A. Hansen et al. (eds.), The Socialist Market Economy in Asia, https://doi.org/10.1007/978-981-15-6248-8_5

Chapter 5, "Reforming State-Owned Enterprises in a Global Economy: The Case of Vietnam" was previously published non-open access. It has now been converted to open access under a CC BY 4.0 license and the Copyright Holder is "The Author(s)". The book has also been updated with this change.

The updated version of this chapter can be found at https://doi.org/10.1007/978-981-15-6248-8_5

(C) The Author(s) 2021

$\mathrm{Cl}$

A. Hansen et al. (eds.), The Socialist Market Economy in Asia, https://doi.org/10.1007/978-981-15-6248-8_13 